\title{
Research on Education and Cultivation of College Students in Innovation and Entrepreneurship
}

\author{
Zhenpeng Zhao \\ School of Art and Design \\ Huanghe Science and Technology College \\ Zhengzhou, Henan, China 450006
}

\begin{abstract}
Colleges and universities are making good efforts to strengthen the education of college students in innovation and entrepreneurship, helping them set up the thoughts of innovation and entrepreneurship and cultivating their consciousness of innovation and entrepreneurship, which meet the requirements of era advance and the demand of market economy development, and also is the inevitable choice for the innovation-oriented construction of our country. At present, the traditional education mode of universities and colleges lacks consciousness of innovation and entrepreneurship, the theory of innovation and entrepreneurship is not complete, the teacher force is weak and the level is low, the entrepreneurial practice is not enough, the innovation and entrepreneurship culture is not strong. The universities and colleges should renew ideas, establish correct view of talents, fully carry out the reform and innovation of entrepreneurship education in the aspects of conception, mechanism, content, method and management, and cultivate the talents of innovation and entrepreneurship in accordance with the requirements of innovation-oriented construction.
\end{abstract}

Keywords-universities and colleges; innovation and entrepreneurship; research on thought

\section{INTRODUCTION}

How the universities and colleges adapt the demands of socialist market economy, deepen education reform, completely promote quality education, cultivate high-quality talents with strong practical ability and innovation spirit is the priority among priorities. Recently, the Ministry of Education publishes the "national top 50 universities and colleges of innovation and entrepreneurship" of 2016, which comes from the summary and propaganda work of original employment of college graduates under the policy background of strongly initiating "popular entrepreneurship and innovation" in our country and is the first time to choose "top 50 of innovation and entrepreneurship" through public appraisal after the "top 50 of employment" per year, so as to summarize and promote the classical experiences of universities and colleges concerning culture of talents of innovation and entrepreneurship, instruction service of employment and highquality entrepreneurship and employment. Under such background, strongly guiding and multi-party encouraging self-employed undergraduates in universities and colleges is a system project having a long way to go, and to well manage to thus great project is to help undergraduates establish thoughts of innovation and entrepreneurship, cultivate their consciousness of innovation and entrepreneurship as well as fully strengthen the quality education of undergraduate innovation and entrepreneurship.

\section{CULTURE CONNOTATION OF QUALITY EDUCATION OF INNOVATION AND ENTREPRENEURSHIP IN UNIVERSITIES AND COLLEGES}

In twenty-first century, the era of innovation and entrepreneurship, talents need to possess the quality and ability of innovation and entrepreneurship. As the new engine of the economic development of China, innovation and entrepreneurship has been a wave of the era. The government, society and university pay more attentions on the strategic deployment of innovation and entrepreneurship as well, and the entrepreneurship education will be one of the points of strength of education reform in universities for a long time in the future while strong entrepreneurship culture is one the indispensable factors of powerfully promoting entrepreneurship education. Nowadays, universities contend not only limited to the competition of teaching facilities, teachers, major construction and other hard powers, but also in the guidance of soft powers, such as the campus culture and university spirit. The quality education culture of innovation and entrepreneurship in universities and colleges is an important composition of campus culture, the sum to material wealth and spiritual wealth created by teachers and students in university education of innovation and entrepreneurship and entrepreneurial practice, including the value orientation, spirituality, behavior customs and stand of behavior formed in the process of entrepreneur's entrepreneurial practice, creating value and promoting economic development, and a special group psychological quality, social ideology and cultural atmosphere related to entrepreneur. In addition to the abovementioned common connotation of social culture, the quality education of innovation and entrepreneurship in universities and colleges also bears the mission of cultivating undergraduates' correct value, outlook on world and life based on its special identification and status. Without excellent humanistic culture, the universities and colleges will be hard to progress and develop in the society, and the braving in struggle, pioneering and no fear of failure borne by the quality education culture of innovation and entrepreneurship in universities and colleges are the classical representatives of excellent traditional cultures required by the current undergraduates as well as the good qualities necessary for 
masses in current development of society, which provide possibilities for students in universities and colleges to understand entrepreneurship, master entrepreneurship skills, provide entrepreneurial practice and promote entrepreneurial effect.

\section{CURRENT SitUATION OF QUALITY EDUCATION OF} INNOVATION AND ENTREPRENEURSHIP IN UNIVERSITIES AND COLLEGES

\section{A. The Universities and Colleges of Quality Education of Innovation and Entrepreneurship Led by Classroom Education}

This kind of universities set innovation and entrepreneurship as a course with separate requirement of credit system and systemic talent culture scheme, it permeates the theory of "innovative thoughts and entrepreneurship education" into each course and daily leaning life, especially make great efforts to strengthen practical teaching link, intensify students' practical ability of operation and stipulate more class hours of practical teaching link in talent culture scheme, require departments establishing practical teaching system adapting to the practical teaching in the era of knowledge-driven economy and continuously explore the road of cultivating talents of innovation and entrepreneurship with distinguished features.

\section{B. The Universities and Colleges of Integrated Innovation and Entrepreneurship, Taking Promotion of Students' Overall Quality as Purpose}

This kind of university is to perfect the educational system of innovation and entrepreneurship with the purpose of students' overall quality based on the top-level design of university and establish the educational system of innovation and entrepreneurship integrated innovation and entrepreneurship universal education platform, innovation and entrepreneurship professional education platform, entrepreneurship tutoring platform and entrepreneurship culture and education. At the same time, it builds entrepreneurship forum, sets electives of innovation and entrepreneurship and entrepreneurship $\mathrm{KAB}$ training and carries out the theoretical courses and practical courses of innovation and entrepreneurship of entrepreneurship policy consulting week, entrepreneurship project road show and entrepreneurship street by utilizing the advantages of campus cultural community, builds strong innovation and entrepreneurship atmosphere in universities and colleges, with great efforts to mobilize the students' entrepreneurship enthusiasm, as well as carries out campus innovative activities in science and technology in all kinds with students widely participated and develops extracurricular activities in entrepreneurship and education through the second classroom. The coordinating and unifying of each aspects make undergraduates acquire favorable effects in the education of innovation and entrepreneurship through mutual supplement with each other.

\section{PROBlems Existing In THE QuALITY EdUCATION OF INNOVATION AND ENTREPRENEURSHIP IN UNIVERSITIES AND COLLEGES}

The "national top 50 universities of innovation and entrepreneurship" of 2016 issued by the Ministry of Education carries out evaluation based on the standard of "innovation and entrepreneurship". Recently, universities and colleges pay more attentions on undergraduates' education of innovation and entrepreneurship and the culture and innovation of practical activities and provide all-round services for the innovation and entrepreneurship of students by combination of the first classroom and second classroom. In addition to the traditional student extracurricular research training activities, the establishment of undergraduate innovation and entrepreneurship training project and undergraduate innovation experiment activities enrich the system. Moreover, there are lots of universities and colleges actively integrate the resources in and around the school, set entrepreneurship schools, entrepreneurial incubator park, invite excellent schoolmates and entrepreneurs to establish out-of-school tutor club and instruct undergraduates carrying out theme exercise activities which receive favorable effects. From nationwide view, the innovation and entrepreneurship work of all universities and colleges are under implementation, but with different effects, concretely shown as:

\section{A. The Traditional Education Mode of Universities Lacks Consciousness of Innovation and Entrepreneurship}

In the students' opinions, they treat selling something or the practice of working while studying as entrepreneurship; some of them consider entrepreneurship as a representative of failing to be employed that one conduct entrepreneurship because one have to due to no work or employment for one; while some of them think that the most important factor for entrepreneurship is capital which is the basement of entrepreneurship, but they neglect the accumulation of knowledge and practice of ability as well as other necessary conditions and factors. Therefore, the traditional education mode of university lacks of consciousness of innovation and entrepreneurship that education of innovation and entrepreneurship only floats on the surface and no deep education and guidance on the students, and in practical operation, it pays little attention on the culture of comprehensive quality, innovation consciousness and practical ability of students themselves.

\section{B. The Theoretical System of Education of Innovation and Entrepreneurship in Universities and Colleges Is Not Complete, the Teacher Force of Entrepreneurship \\ Education Is Weak and the Level is Low}

The theoretical system of education of innovation and entrepreneurship in universities and colleges does not establish its own system, and it does not well blend with other educational system. Teacher strength is still an important factor restricting the undergraduate education development of innovation and entrepreneurship, most of the teachers of foreign course of innovation and entrepreneurship education have the experiences and background of entrepreneurship or investment, while most domestic teachers in this aspect have 
no such practical experience, basically they engage in the business of their own major field depending on theoretical knowledge research. Entrepreneurship education requires teachers having abundant entrepreneurship practical experiences and it is far from enough limiting in theoretical level which may produce an armchair strategist, derail the teaching contents from practice will lead the courses to slight significance. Hence, it is imperative to cultivate more teachers having practical experience to promote the undergraduate education of innovation and entrepreneurship.

\section{Entrepreneurship Practive is Not Enough and the Culture of Innovation and Entrepreneurship Is Not Strong}

In current stage, the education researches on domestic innovation and entrepreneurship mainly bases on the theoretical level, which analyze and evaluate the innovation and entrepreneurship situations on domestic undergraduates on innovation consciousness, entrepreneurship environment, entrepreneurship quality, entrepreneurship team and entrepreneurship base and put forward instructional opinions and suggestions as well, however, generally, it lacks of a suit of complete practical mode of education of innovation and entrepreneurship for students in universities and colleges. Many governments and schools issue some preferential policies of entrepreneurship, provides policy and capital support, but in consideration of operation situation, there still are lots of problems existing in pioneer park, incubator and entrepreneurial base: the management and operation of pioneer parks derail from the education of innovation and entrepreneurship which forms the so-called practical group and theoretical group; the entrepreneurial projects of pioneer park cannot form scale and inheritance development, the structure of team members is not reasonable that most projects are mainly cooperated by students in same major which not integrate the advantages of students in all majors of the universities, far from stepping the society to accept the examination of law of market economic, correspondingly, most entrepreneurship projects ends in separate ways of students after graduation.

\section{College Students' Own Problems}

For undergraduates in such aroused age, on the one hand, they are full of passion and fight as newborn calves not afraid of tigers, while on the other hand, we should know that they still have seen a small part of life, and they are just ignorant, rash and arbitrary. To start up a business means to experience the pain, frustration and hardships as well as loose more personal time and energy. At the beginning of entrepreneurship, students with low adaptive capacity are easily to lose themselves, and the personality of undergraduates at this time is in the period of reconstitution and their thoughts are not that independent, hence, it is still hard for undergraduates to adapt the pain and frustration examination at the beginning of entrepreneurship.
V. MEASURES FOR CULTURE OF EDUCATION OF INNOVATION AND ENTREPRENEURSHIP IN UNIVERSITIES AND COLLEGES

\section{A. Education of Multiple Consciousness of Innovation and Entrepreneurship}

Cultivating the undergraduates' thoughts of innovation and entrepreneurship requires strengthening education of multiple consciousness of innovation and entrepreneurship, changing the traditional education mode, exploring new training mode integrated knowledge, ability and quality to adapt the demands of social development. Such as cooperation consciousness, cooperation and mutual benefits are the big trend of marketoriented operation and win-win if cooperation is a representative case in market-oriented economy which is a kind of synergic team spirit. Market innovation consciousness, market respects initiative, and no innovation will cause no development, how to stand out of numerous similar products in the market, it requires new selling points to attract customers which means it requires market innovation consciousness. Hardworking and enterprising consciousness, most entrepreneurs start from nothing, win the world from poor and blank and experience hard starting, financing and selling, and achieve harvest as well as realize stable development of performance after experiencing the hard entrepreneurship beginning. Cultivating students from entrepreneurship consciousness to entrepreneurship spirit and then to entrepreneurial knowledge and technology on entrepreneurship education in different forms and stages, make them want to start up business, be able to startup and manage to startup, so as to avoid the disharmony between the entrepreneurship consciousness and entrepreneurship technologies and lay a favorable foundation for the students' entrepreneurship in the future.

\section{B. Establishment of Systemic Project of Education of Innovation and Entrepreneurship in Universities and Colleges}

In order to promote education of innovation and entrepreneurship effectively, make it be accepted in wider fields under correct guidance and leading, and implemented at deeper level, the universities must establish and perfect the leading group of innovation and entrepreneurship composed of leaders, supervision experts, related functional departments and responsible persons of each teaching unit, and establish corresponding branches of functional departments in the universities, through which, it can guide and lead the entrepreneurship education and activities all over the school and fields. The universities shall, according to the policy requirements concerning "popular entrepreneurship and innovation" issued by the nation and location and combining their own practices, initiatively adjust the objectives of talent training, set courses of innovation and entrepreneurship, construct complete course system of entrepreneurship consciousness education, strengthen the building of teachers, establish a teacher group adapting the education of innovation and entrepreneurship consciousness, enrich the entrepreneurship education practical activities, build favorable social atmosphere of undergraduate entrepreneurship, set up 
evaluation system and establish effective security mechanism of entrepreneurship education. The university should practically promote the reform of innovation and entrepreneurship education, encourage and support selfemployed undergraduate, establish and perfect the guidance service system of innovation and entrepreneurship in universities as well as cultivate the consciousness of innovation and entrepreneurship of undergraduates.

\section{Put the Entrepreneurship Education Effect into Teaching Level Quality Assessment System}

Assessment on teaching level and teaching quality is an important measure to examine the level of running a school as well as the teacher team, teaching condition and utilization, teaching construction and reform, teaching management, study style and teaching effect, as well as an important mean to promote university discover problems and urge colleges to promote level of running school. The national Ministry of Education needs to evaluate with professional assessment system, bring the performance of universities' innovation and entrepreneurship education into the whole system of teaching level and quality project, so as to make the universities treat the education of innovation and entrepreneurship education seriously.

The university shall, according to the requirements of UNESCO, make clear that bring the courses of innovation and entrepreneurship into the talent training scheme, bring the objectives of innovation and entrepreneurship into the teaching objectives of school education as soon as possible, and organically integrate the teaching contents of courses of innovation and entrepreneurship with the public basic course, professional elementary course, courses in specialty and general education courses of the whole school, permeate the theory and contents of entrepreneurship education in the teaching of public courses, subject curriculum and courses in specialty. The Ministry of Education shall make the propaganda work of innovation and entrepreneurship in national universities, strongly commend the classical universities of innovation and entrepreneurship, popularize and exchange successful experience of entrepreneurship and promote the joint development of entrepreneurship education in universities.

\section{CONCLUSION}

In the notice of Basic Requirements for General Undergraduate Schools on Entrepreneurship Education Teaching (on trial) issued by the Ministry of Education, it is pointed that carrying out entrepreneurship in general universities and colleges is the strategic measures serving the nation to enhance conversation of economic development modes, establishing innovation-oriented country and country rich in human resource, is an important approach to deepen teaching reform in higher education, enhance quality of talent training and promote all-around development of undergraduates and an important measure to carry out entrepreneurship-driven employment and accelerate full employment of college graduates.
The connotation of education is to train talent, the education of innovation and entrepreneurship in universities shall cultivate lots of talents adapting the "new normal" development of economy with innovative spirit and innovation capacity. Carrying education of innovation and entrepreneurship in universities and providing concretely feasible modes of new-type talent training in our country, not only solving the employment problems but also is the inevitable requirement for establishing innovation-oriented country. Higher education in knowledge economic age not only refers to knowledge and academic education, but also the education of creativity, innovation and entrepreneurship. The universities shall renew conceptions, set up correct talent view according to the requirements of ages and market economic development, as well as fully conduct reform and innovation of entrepreneurship education on conception, mechanism, contents, methods and management operation, more and better cultivate innovative and entrepreneurial talents serving for the socialist modernization.

\section{REFERENCES}

[1] Li Shijiao. Construction of Undergraduate Innovative and Entrepreneurial Education System [J]. Heilongjiang Researches on Higher Education, 2011,09:119-121.

[2] Zhou Mindan. Thoughts on Effective Approaches for Entrepreneurship in Universities [J]. Technoeconomics \& Management Research, 2011,09:37-40

[3] Basic Requirements for General Undergraduate Schools on Entrepreneurship Education Teaching (on trial) [N]. The Ministry of Education of the People's Republic of China, 2012,11,13

[4] Lin Yuliang, Zeng Chen. Analysis and Construction of Innovation and Entrepreneurship in Universities [J]. Heilongjiang Researches on Higher Education, 2016,05:108-110.

[5] Zhuang Jinyong. Research on Cultivation Patch of Entrepreneurship in Universities [J]. Journal of Fuqing Branch of Fujian Normal University, 2016,02:89-92.

[6] Zhang Yu. Research on Entrepreneurship in Universities under the Perspective of Developmental Student Work $[\mathrm{J}]$. Intelligence, 2016,08:25.

[7] Cui Huibin, Sui Binyuan. Research on Incentive Policy of Undergraduate Innovation and Entrepreneurship [J]. Journal of Tianjin Institute of Financial and Commercial Management, 2014,05:54-56.

[8] Zhang Shujun, Liu Taiqiang, Hao Peifeng. Exploration of Cultivation Modes of Innovation and Entrepreneurship Education [J]. Liaoning Education Research, 2003,01:68-70.

[9] Wang Sen. Discussion on the Construction of Entrepreneurship Education System in China $[\mathrm{J}]$. China Collective Economy, 2012,10:190+195. 